brandeis.edu/j-caste
CASTE: A Global Journal on Social Exclusion

Vol. 1, No. 2, pp. 31-50

October 2020

ISSN 2639-4928

DOI: 10.26812/caste.v1i2.199

\title{
Leisure, Festival, Revolution: Ambedkarite Productions of Space
}

\author{
Thomas Crowley'
}

\begin{abstract}
This article analyzes the town of Mahad in the state of Maharashtra, using it as a lens to examine protests and commemorations that are inseparable from Ambedkarite and Neo-Buddhist transformations of space. A key site of anti-caste struggle, Mahad witnessed two major protests led by Dr. B.R. Ambedkar in 1927: the claiming of water from Chavdar Tale, a tank located in a upper caste neighbourhood; and the burning of the Manusmriti. These events are commemorated every year with large-scale festivities. The article analyzes the ways that these protests and festivities have worked to produce a distinctly Ambedkarite space, one that is radically counterposed to hierarchical, Brahminical productions of space. Exploring the writings of Ambedkar and more recent Ambedkarite scholars, and putting these texts into dialogue with the spatial theories of Henri Lefebvre, the article contributes to a growing international literature on the spatiality of caste. The Navayana Buddhism pioneered by Ambedkar has been analyzed in terms of its ideology, its pragmatism, and its politics, but rarely in terms of its spatiality. Drawing on Lefebvre helps flesh out this spatial analysis while a serious engagement with neo-Buddhist practices helps to expand, critique and globalize some of Lefebvre's key claims.
\end{abstract}

\section{Keywords}

Ambedkar, Lefebvre, Mahad, neo-Buddhism, festival, revolution

\section{Introduction}

The market town of Mahad sits on a small plateau in the foothills of the Sahyadri mountains in the western Indian state of Maharasthra. During the monsoon, heavy

\footnotetext{
'Geography Department, Rutgers University,

Lucy Stone Hall, 54 Joyce Kilmer Avenue Piscataway, NJ 08854-8045

E-mail: thomas.crowley@rutgers.edu
}

(C) 2020 Thomas Crowley. This is an open access article distributed under the terms of the Creative Commons Attribution License, which permits unrestricted use, distribution, and reproduction in any medium, provided the original author(s) and source are credited. 
rains wash down the hills and seep into the ground, recharging the ponds and tanks that were historically the main water supplies for the town but are now used primarily for leisure and recreation. The most famous of these water bodies is Chavdar Tale, located just north of the main market road, surrounded on all sides by upper-caste households. This site is now recognized as foundational to the modern anti-caste struggle, memorialized for the day in 1927 when Dr. B.R. Ambedkar and thousands of other Dalits drank water from it in defiance of caste strictures. Every year on March 20, thousands of visitors - or perhaps more accurately, pilgrims (cf. Zelliot, 2011) descend on Mahad to commemorate that transformative day.

This article is an exploration of Chavdar Tale's shifting political and affective geographies, and of the complex links between geography and religion. In the Ambedkarite calendar, March 20 is known as Kranti Din -the Day of Revolution. As Soumyabratta Choudhury (2018) has argued, the Mahad satyagraha, with its emphasis on the equality of all humans, was a revolutionary event of global importance that placed Ambedkar in a line of radical egalitarian thinkers spanning from ancient Greece to the present day. And yet today, the space around Chavdar Tale seems most notable for its everydayness, its ordinary use by people of all castes in what remains a caste Hindu-dominated neighbourhood. Is Chavdar Tale still, then, revolutionary? Or have such spaces become commercialized, commoditized, and sanitized, as some critics have argued? (cf. Rege, 2008).

The article approaches these questions by turning to the speeches and writings of Ambedkar and more recent Ambedkarite scholars, and putting these texts into dialogue with the spatial theories of the French Marxist philosopher Henri Lefebvre. A prolific author, who produced pioneering analyses of a wide range of contemporary processes, from capitalism's colonization of everyday life (Lefebvre, 2014), to the increasing centrality of urbanization (Lefebvre, 2003b), Lefebvre has been particularly influential in elaborating a critical analysis of space and its role in both reproducing and contesting social hierarchies. In his book The Production of Space (1991) and other works, Lefebvre theorizes space not as a passive backdrop to historical events but as an actively-produced, hotly-contested, contradiction-riven realm of thought, praxis, and everyday experience.

Such theorizations resonate with the small but growing body of literature on the spatiality of caste (Rege, 2008; Guru, 2012; Chairez-Garza, 2014; Lee, 2017; Gorringe, 2018). This literature has sought to recover neglected spatial elements of Ambedkarite thought and practice, and to explore how the spaces of caste can be theorized in a more explicit way. For instance, Sharmila Rege (2008, p. 17) notes:

Space and spatial strategies of appropriation, deployment and control have been of crucial significance in maintaining hierarchical relations of caste. The Ambedkarite movement has contested this through claiming the right to public water resources, temples, and educational centres by dropping negative rights to spaces such as 'watan' and denouncing the 'space' within Hinduism.

Several theorists of caste have been drawn to Lefebvre (1991) because his ideas help conceptualize how 'every society... produces a space, its own space' (p. 31); further, in hierarchical societies, the production of space inevitably involves the creation of centers and peripheries - evidenced, in the Indian context, by the literal spatial marginality of Dalit bastis or colonies, typically situated outside village limits or on marginal urban land. 
Guru (2012), for instance, appreciates Lefebvre's argument that space is often actively produced with the goal of 'controlling people in finite, enclosed and divided sites' (p. 78). Along similar lines, Lee (2017) invokes Lefebvre's argument that ideologies are ineffective unless they are inscribed in particular spaces, through particular spatial practices (p. 470), while Gorringe (2018) draws on similar passages in Lefebvre to suggest that such dominant ideologies are also resisted through spatial practices.

These invocations of Lefebvre have, for the most part, remained fairly general, relying on his broad arguments about the importance of space for the (always contested) reproduction of social relations. In contributing to this emerging conversation, I am particularly interested in Lefebvre's specific reflections on leisure and the revolutionary potential of the festival. While Lefebvre's writings on these themes may illuminate particular aspects of Mahad's history and its present, I suggest that the unfolding events in Mahad also enable us to question some of Lefebvre's more linear and teleological assumptions and to thus expand his theories in important ways. Specifically, Ambedkarite spaces, when codified as sacred, complicate Lefebvre's suggestions about the withering away of religious space, while opening up new possibilities for transformative politics.

In the following sections, I begin with the Mahad Satyagraha of 1927, exploring why it is accorded such significance in the Ambedkarite tradition, how it resonates with previous revolutionary events, and what a Lefebvrian perspective might contribute to our analysis. I then turn to more recent history, including the use of Chavdar Tale for everyday leisure and for more spectacular bi-annual events, which both support and subvert Lefebvre's theorizations and expectations regarding the evolution of spatial politics. Finally, I reflect on what it might take for the festive nature of the space to more fully fulfill its role as a site of revolution.

\section{An Anti-Caste Revolution?}

In The Production of Space, Lefebvre (1991) offers several suggestive remarks about the creation of centers and peripheries, which have great salience for the analysis of Mahad. Lefebvre argues that 'Each period, each mode of production, each particular society has engendered (produced) its own centrality'; however, within particular societies or even particular urban spaces, 'centrality is movable' (p. 332). Further, centers are not produced ex nihilo but are built upon previous complexly-intertwined inscriptions upon space. Lefebvre famously compares space to a flaky pastry, in which 'social spaces interpenetrate one another and/or superimpose themselves upon one another' (p. 86).

Certainly, Mahad - in 1927, and in the present day - is a particularly concentrated point of intertwined social spaces. For centuries before the satyagraha, Mahad was an urban centre in its own right, as a market town for its surrounding hinterland and (until recently) as a port on the Savitri River, connecting the interiors of Maharashtra to the Arabian Sea. But in the beginning of nineteenth century, Mahad was increasingly pulled into the orbit of the expanding, industrializing city of Bombay (now Mumbai).

Mahad emerged as a revolutionary hub in the 1920s because of such larger relations. As Gail Omvedt (1994) has asserted, Bombay Presidency was the "most industrialized and the most politically and sociologically vigorous of provinces of British India' (p. 139). In the Presidency, the 'vigorous village economy linked to a 
turbulent industrial metropolis was a unique configuration... Such linkages provided the main social foundation for the broad democratic movements of Maharashtra' ( $p$. 141). Flows of migrants to Bombay from Mahad and surrounding areas led to an exchange, not just of money and jobs, but also of activism, revolutionary ideas, and strategies for political organization.

The Konkan region surrounding Mahad had a history of anti-caste activism before the satyagraha, in part due to the presence of Dalits who had served in the British military and thus, had accessed some degree of social mobility (cf. Omvedt, 2011, p. 7). Several anti-caste leaders from this region organized the March 1927 event and convinced Ambedkar (whose ancestral village was in the Konkan, and who by then was based in Bombay) to preside. Initially, the organizers of this programme were not planning for revolutionary action. Their aims were more modest: to convene a meeting of activists and politically conscious Dalits in Kolaba district (present-day Raigad district). Organizers were energized by the turnout - around three thousand people came from around the district - and, on the penultimate night of the conference, they began discussing the possibility of drinking from Chavdar Tale as a way to end the event on assertive note.

Conference attendees found out about this plan only as the final speeches were ending, and one of Ambedkar's main allies proposed that the assembled crowd march to Chavdar Tale and drink its water. As Ambedkar (1989, p. 249-250) himself narrates:

The Hindus who had exhorted them to be bold and begin fearlessly to exercise their rights, instantly realized that this was a bombshell and immediately ran away. But the effect upon the untouchables was very different. They were electrified by this call to arms. To a man they rose and the body of 2,500 untouchables led by me and my co-workers marched in a procession through the main streets. The news spread like wild fire while crowds thronged the streets.

After marching through the central streets of Mahad, Ambedkar and thousands of others drank water from Chavdar Tale. The organizers then returned to their guest house and the conference participants begin to arrange for their journeys back home. During this lull, a priest from a nearby Hindu temple started spreading rumors that the conference attendees were going to try to enter the temple. A group of upper-caste men gathered and began beating up the conference attendees with sticks. Twenty were seriously injured, and dozens more were wounded. Only the intervention of Ambedkar, with grudging help from local law enforcement, brought the violence to an end. The success of the initial action was thus clouded by the violence that followed.

Ambedkar returned to Bombay and began to consider next steps. After consulting with other anti-caste leaders, he decided to launch a satyagraha demanding that 'untouchables' have the right to drink from Chavdar Tale (which by this time should have been their legal right, given a resolution in the Bombay Assembly opening publicly-funded infrastructure to all individuals).

The satyagraha culminated in a December gathering in Mahad, attended by roughly ten thousand people. By this point, Ambedkar had recognized the potentially revolutionary significance of the event, and began to ascribe more importance to the March conference and the continuing fight to drink water from Chavdar Tale. In a speech on December 25, Ambedkar compared the Mahadsatyagraha to the French Revolution, and specifically to the formation of the National Assembly in June 1789. Ambedkar argued that, just as that Assembly dissolved the system of three hierarchical 
'Estates' in France, the Mahad satyagraha sought no less than dissolving India's hierarchies, in the form of the varnashrama system (Teltumbde, 2016, p. 207-8).

Following this speech, Ambedkar joined some of his supporters in burning pages from the Manusmriti. This was more than just a book burning; the group staged an exuberant mock cremation for the legal text, with 'untouchable' priests and holy men brought on stage to perform funeral rites for the regressive tome. Specifically, Ambedkar and his co-organizers read out and burned the parts of the text that related to the social exclusion of women and lower-caste groups, and the violent punishments prescribed for those who transgress orthodox bounds of caste and sex.

But the satyagraha had a somewhat anti-climactic end. After intervention by the courts and imperial administration, Ambedkar and his colleagues decided to call off the planned march to Chavdar Tale, and instead to pursue the case through the legal system. The case dragged along for much of the next decade, eventually making its way to the Bombay High Court. After many appeals and delays, it was finally decided in Ambedkar's favour in March 1937.

However, by this time, Ambedkar had already become disillusioned with the case. A year and half earlier, on October 12, 1935, he had suggested that it was time to end to the Mahad satyagraha, as well as the ongoing Kalaram satyagraha for temple entry, since they had failed to budge caste-Hindu public opinion (cf Omvedt, 2004/2013, p. 106). The very next day, he gave his famous speech at Yeola, arguing that the only real option for Dalits was conversion, declaring 'I will not die a Hindu'. The resolution passed at the Yeola conference emphasizes the connection between the intransigence of caste Hindus, the decision to end the 'satyagraha at the Kalaram Temple in Nasik and at Chowdar Tank in Mahad' and the conclusion that Dalits should make their 'own society independent of the so-called touchable class' (Zelliot, 2004, p. 149-150).

\section{Revolutionary Antecedents of Mahad}

Given the way that the protest petered out, scholars like Anand Teltumbde (2016) have questioned how apt it is to compare it to the national-scale (not to mention successful) French Revolution. Teltumbde's larger critique is useful for situating the limits of the Mahad satyagraha, but it is also possible to read Ambedkar's speech less literally. In his speech, Ambedkar invoked the French Revolution in a particularly rhetorical way - to emphasize the norms of liberty, equality, and fraternity - rather than making a detailed or literal comparison to the historical events of Europe in the late eighteenth century.

This is not to say, however, that historical comparisons of revolutionary events are not fruitful. Especially if one is attentive to the different conjunctures in which they occur, a comparison of such events has the potential of illuminating important elements of their unfolding, their successes, their failures, and their legacies. Again, Lefebvre provides one potential lens for doing so, given his attention to the spatiality of revolutions. Specifically, Lefebvre's in-depth analysis of the Paris Commune of 1871 provides fertile grounds for 'relational comparison' (cf. Hart, 2016) with the Mahad Satyagraha. The Commune, a radically egalitarian body that governed France's capital for less than two months before being brutally repressed, has been a touchstone for theorists and practitioners of radical democracy, socialism and anarchism, from those alive at the time, including Marx and Kropotkin, to later theorists like 
Lefebvre. Strikingly, some participants in the Commune, notably the socialist leader Benoit Malon, saw themselves as part of a global struggle for freedom that included events like the 1857 Indian uprising against British rule (cf. Ross, 2015, p. 33).

Continuing this global conversation, we can understand both Paris in 1871 and Mahad in 1927 as urban revolutions. Both strove to reconfigure the sedimented hierarchies of urban spaces as part of larger revolutionary projects. In his analysis of the Paris Commune, Lefebvre brings particular attention to the way in which the communards made claims to centrality - not just politically, but spatially. Lefebvre later theorized such claims under the guise of the 'right to the city.' As he wrote, 'The right to the city is thus the right to be-to be an integral part of the city... The right to the city is a right to produce that centrality - the right not to be marginal' (Mitchell \& Villanueva, 2010, p. 671; emphasis Lefebvre's).

For Lefebvre, the Paris Commune must be situated in the urban context of Second Empire France, when Baron Haussman demolished centrally-located working-class neighbourhoods in order to make way for his famous boulevards and other urban renewal projects. Lefebvre sees the Paris Commune as a strategy of the expelled working classes, who take advantage of the political chaos of the Franco-Prussian wars to return to the Parisian city centre, and enact a radical, creative expansion of their claims to spatial and political centrality.

Seen in this framework, Dalits drinking from Chavdar Tale can be seen, not as a return to centrality, but something perhaps even more radical: a bold new claim to centrality, defying a caste system that had relegated 'untouchables' to the literal and symbolic margins for more than a millennium. In an article reflecting on the Mahad experience, Ambedkar (1989, p. 248) highlights the centrality of Chavdar Tale, noting:

Mahad is a business centre... The Untouchables either for purposes of doing their shopping and also for the purpose of their duty as village servants had to come to Mahad... The Chawdar tank was the only public tank from which an outsider could get water.

The right to drink water (both symbolically and literally central to human existence) is thus connected to the ability to access water in a central business location; this gives a particular spatial resonance to Ambedkar's well-known claim that the Mahad satyagraha's purpose was 'to establish that we are also human beings like others'(Teltumbde, 2016, p. 207).

Though Dalits' claim to centrality in Mahad in March 1927 was even shorter-lived than the Paris Commune, it is also rightly looked up on as a radical break from the past, in part because of its spatial boldness - as Ambedkar noted, even the savarnas (socalled 'upper' castes) who initially supported the March programme ran away when they heard about the radical direct action being planned. Lefebvre's reflections on the spirit of the Paris Commune could just as easily describe the impromptu decision to drink from Chavdar Tale, and the electrifying effect it had on the assembled crowd: it showed 'a basic will to change the world and life as it is, and things as they are, a spontaneity conveying the highest thought, a total revolutionary project' (Lefebvre, 2003a, p. 189).

If we include the December 25, 1927 burning of the Manusmriti as part of a longer wave of activism in Mahad, then even more parallels emerge between Mahad in 1927 and Paris in 1871. In both cases, the destruction of symbols of the old was seen as a key act in laying the ground for the new. The communards targeted several structures built by Haussman, including the prefecture of police. As cultural critic Gavin 
Grindon notes, Lefebvre does not see the 'destructive' acts of the Paris Commune as merely vandalism. Rather, 'Against Haussmann's urbanism, [Lefebvre] recalls [this destruction] as a positive creative act, the necessary first stage of revolutionary urbanism'(Grindon, 2013, p. 215). In a similar way, the burning of the Manusmriti was both subversive and creative, a light-hearted, mocking critique of caste law, and an invitation to create new ways of living.

In both cases, too, there is an intertwined critique of religion and gender, or rather the way that particular religious doctrines are employed in the service of patriarchal practices. Kristin Ross (2015) has emphasized both the anti-clerical flavour of the Paris Commune and its liberatory gender politics - one of the first steps of the Commune was to establish a Women's Union. Similarly, burning the Manusmriti was a skewering of caste's religious justifications, as well as its gender hierarchies. Even today, some Ambedkarite women's organizations celebrate December 25 as Mahila Mukti Diwas (Women's Liberation Day). As both historical events show, spatial politics are inextricably entwined with ideologies of both religion and gender, and all of these threads must be followed in tracing the potential implication of liberatory movements.

The immediate result of both these events, however, was not liberation, but violent repression - the savarna attack on Dalits, and the much larger bloodshed of the Paris Commune in which the French army brutally killed thousands of communards. The different scales of the violence also reflect the different scales of the events and the spatial configurations that underlay both their emergence and their repression. The Paris Commune was only possible because of the power vacuum caused by the Franco-Prussian War. And once the Commune formed, it existed in a more or less constant state of siege. It was a centralized urban space cut off from an indifferent or even hostile countryside, with the French state consciously closing off all points of communication between town and country. This spatial vulnerability - alongside the perceived threat of the Commune on a continent-wide scale - led to its brutal extermination, as the Prussian state released French prisoners of war for the express purpose of crushing the Commune (cf. Marx, 1933).

The geography of Dalit struggle, on the other hand, was much more variegated, as Dalits faced oppressive social and spacial structures in villages, small towns and big cities alike. Despite the later centrality of Bombay to Dalit activism, anti-caste organizing was not confined to the metropolis. Early twentieth century activism, often led by military pensioners, took place mostly in villages and smaller towns, including Mahad; the 1927 Mahad satyagraha was something of a turning point, since much of its organizational energy came from Bombay.

In short, the movement had both allies and enemies at multiple scales. Negotiation between these scales allowed events like the Mahad satyagraha to emerge, but the saturation of caste hierarchies at multiple scales also provoked violent backlash to the satyagraha - not just at the event itself, but with the threat of savarna economic boycotts when the Dalit protesters returned to their places of residence, including potential seizure of their lands (cf. Rao, 2009, p. 79). The violence of savarna reaction led Ambedkar to term it a 'religious war' (Rao, 2009, p. 84). But, to use Gramscian terms, this was more a war of position (made up of many small, 'molecular'aggressions and assertions, dispersed over multiple spaces and times) than the concerted war of manoeuvre that ended the Paris Commune (cf. Gramsci, 1971, p. 110). 


\section{Events and Aftermaths}

Ambedkar's 1935 decision to end the satyagraha and advocate conversion suggests a certain disillusionment with the struggle of Mahad, spurred by his recognition of the intransigence of savarna socio-spatial claims to superiority. The Commune's bloody end too suggests the brutal intransigence of the European bourgeoisie. Arguably, capitalism, casteism, and patriarchy have only become more entrenched since the repression of these two moments of revolutionary festivity. What then happens after the 'failure' of a movement? Or rather, what does it mean to see the aftermath of these events as more than just a failure? Here, I am inspired by Kristin Ross' (2015) reflections on the afterlives of the Paris Commune, or what she terms 'not the memory of the event or its legacy... but its prolongation, every bit as vital to the event's logic'(p. 6).

How has the Mahad satyagraha been prolonged? One could argue that the initial announcement of conversion - and Ambedkar's decades-long search for an appropriate conversion strategy - emerged in part out of his reflections on Mahad and the reaction the satyagraha provoked. Further, in the Mahad protests, one can detect the seeds of arguments Ambedkar would make in later works, particularly in his famous undelivered speech, Annihilation of Caste.

In this work, Ambedkar draws his argument to a close by making a distinction between religions based on principle and religions based on rule. Referencing the Vedas and the Smritis (with Manusmriti not named, but clearly implicated in the latter category), Ambedkar (1979a) states, 'What is called Religion by the Hindus is nothing but a multitude of commands and prohibitions. Religion, in the sense of spiritual principles, truly universal... is not to be found in them.' He continues: 'To put it in plain language, what the Hindus call religion is really law or at best legalized classethics. Frankly, I refuse to call this code of ordinances, as Religion' (p. 75).

Ambedkar's earlier burning of the Manusmriti is a foreshadowing of this argument. As a practical enactment of his rejection of religion-as-rule, Ambedkar's mockcremation ceremony for the text highlights the gendered injustices of religious law - a theme that extends back to Ambedkar's (1979b) earliest writings on caste, which emphasize how caste endogamy is maintained by controlling women's sexuality. The protest also underlined the explicit and implicit ways that legal orders buttress casteist productions of space.

It is notable that Ambedkar wrote Annihilation of Caste in 1936, just a year after calling off the Mahad satyagraha and calling for conversion, and months before the Mahad case was finally decided by the Bombay High Court. Following this case in court over the course of a decade, Ambedkar would have witnessed the strategy of his savarna opponents, who claimed that Chavdar Tale was akin to private property because it abutted a temple, and hence was the domain of the upper castes. As Rao (2009) notes, 'The distinction between, and the conflation of, sacred and civic space was creatively mobilized by caste Hindu plaintiffs'(p. 84). It is clear, then, that Ambedkar's fight against religion-as-rule does not apply only to texts like the Manusmriti, but to his contemporaries' attempts to meld savarna religious sensibilities and British-style property law.

Thus Ambedkar's reflections on the continuing struggle in Mahad likely informed his arguments in Annihilation of Caste and his calls for conversion out of Hinduism, which finally culminated in his conversion to Buddhism in 1956, months before his death. The reverberations of this action carry into the present day, and have shaped the continuing political and religious significance of Chavdar Tale. 


\section{Commemorating Kranti Din}

In one of her last publications, capping a career of pioneering scholarship on the Ambedkarite movement, Eleanor Zelliot (2011) draws our attention to the Ambedkarite pilgrimage circuit that emerged in the decades after Ambedkar's death. Zelliot emphasizes the importance of mass gatherings with fixed dates over the course of the calendar year, as a way of commemorating, renewing, and strengthening the Ambedkarite movement. While Zelliot focuses on three pilgrimage sites, Rege (2008) gives a fuller accounting, listing 'December 6 at Chaitya bhoomi in Mumbai, October 14 at Diksha bhoomi in Nagpur, January 1, at Kranti Stambh in Bhima Koregaon, and March 20 and December 25 in Mahad'(p. 16).

The title of Zelliot's article, 'Connected People,' is a nod to Anne Feldhaus' book Connected places: Region, pilgrimage and geographical imagination in India (2003), which traces the sacred geographies of various Hindu pilgrimages in Maharashtra. Zelliot's title implies that the Ambedkarite movement is creating an alternative geography, one that crucially inscribes neo-Buddhist symbols and activities on the broader landscape. Zelliot suggests that the gatherings at Nagpur are the largest - the one commemorating the fiftieth anniversary of Ambedkar's conversion to Buddhism drew roughly one million people - but all the gatherings have neo-Buddhist overtones, with monks and nuns singing Pali chants, and a wide availability of Buddhist literature.

While some scholars (cf. Teltumbde, 2018) have questioned the focus on Ambedkar icons and religious symbolism at the expense of more material issues, others have argued that the symbolic is not necessarily divorced from the material, and that particular Ambedkarite symbols are also part of larger spatial struggles. As Gorringe (2018) asserts, 'The icon of Ambedkar is open to various uses and interpretations. It is neither inherently radical nor necessarily an empty symbol. Its import, in sum, rests on the meanings that it is made to bear and how it is presented'(p. 337). Gorringe's conclusion resonates with the findings of other scholars (for instance, Tartakov, 1990; Jaoul, 2006; and Jain, 2014), all of whom underscore the important spatial politics of Ambedkarite iconography; Jain (2014) particularly emphasizes the materiality of Ambedkarite statuary and monuments in a way that troubles an easy symbolicmaterial divide.

Certainly, the danger of appropriating Ambedkar should not be brushed aside, especially given the current push by right-wing nationalist forces to use Ambedkar to back a project which Ambedkar himself vehemently opposed: Hindu Raj. But an analysis of the continuing salience of Mahad can suggest the tensions and ambiguities in the popularity of Ambedkarite symbols and spaces.

There were small commemorative gatherings in Mahad even during Ambedkar's lifetime, but large-scale annual celebrations of the Mahad satyagraha began in earnest on the event's fiftieth anniversary, March 1977. As Teltumbde (2018) argues, it was around this time that Prakash Ambedkar emerged as a figure who challenged the political establishment. The powerful sugar baron Sharad Pawar - soon to become Chief Minister of Maharashtra - began to prop up Ramdas Athawale as a way to divide the Dalit movement and channel Ambedkarite energies in a less threatening direction. Athawale began to take a major role in organizing the yearly celebrations in Mahad, and Sharad Pawar's government helped to fund a major renovation of Chavdar Tale, which included draining part of the tank to make room for a park and a function hall. 
This space, however, has a life of its own, which has developed over the years, and which cannot be reduced to Pawar's calculating intentions. The park around Chavdar Tale is a bustling place that combines aspects of leisure, sociality, and the sacred. Lovers amble around the park's lawn. Kids run around shrieking while their parents follow behind them at a leisurely pace. Groups of old men sit huddled together. Teenagers pose with each other and take selfies.

But in this everyday space, the marks of Ambedkar and of neo-Buddhism are clearly visible. At one of the main entrances, there is a decorative gateway that bears a remarkable resemblance to the gate at the ancient Buddhist stupa in Sanchi - a design also replicated in the neo-Buddhist Dikshabhoomi in Nagpur. The gateway is adorned with elephants and topped with an Ashoka Chakra (Figure 1). At the end of the park is an entrance to a walkway that leads to the centre of the pond. Here, on a diamondshaped platform, is a statue of Dr. B.R. Ambedkar in his signature suit and tie (Figure 2). Visitors must take off their shoes when entering the walkway, as if entering a temple, while the park's watchman keeps a careful eye on those who come and go.

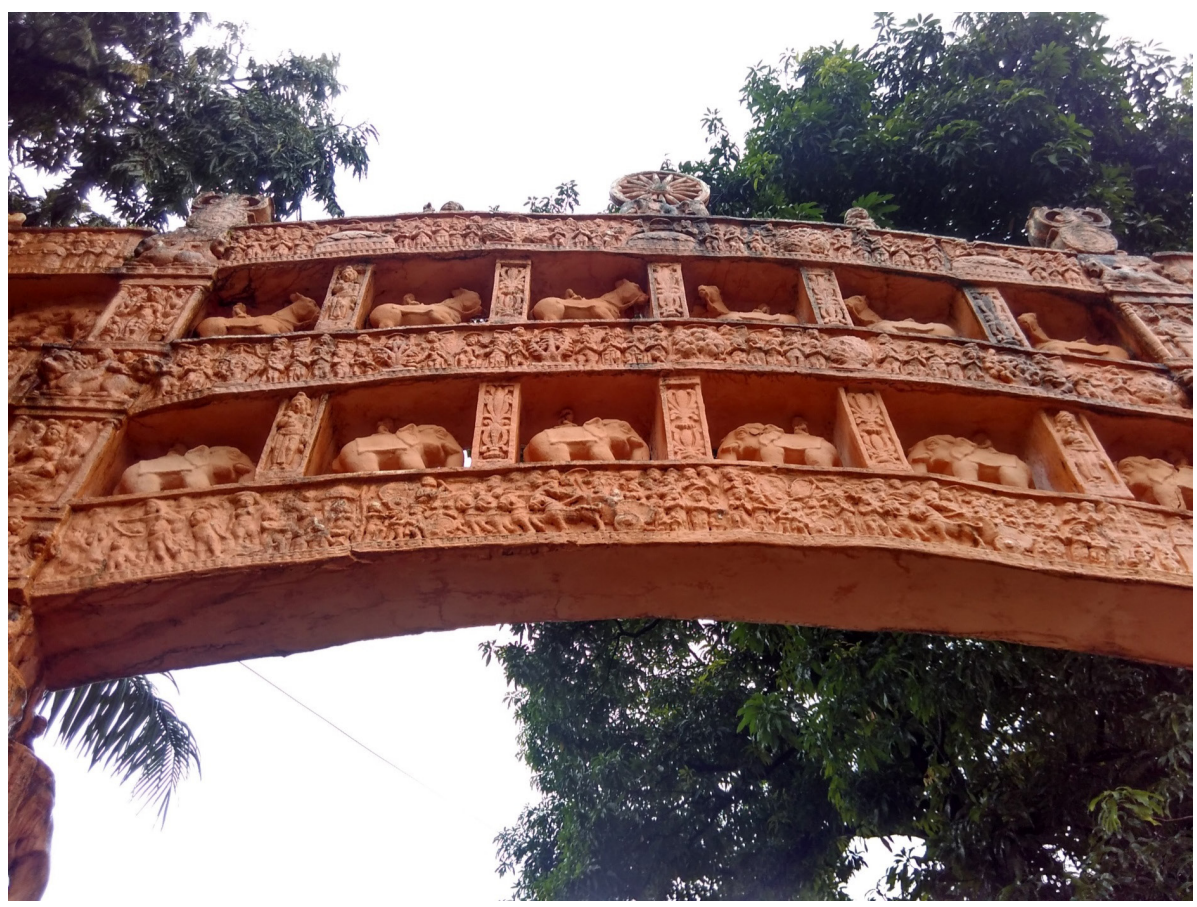

Figure I: Stupa-like gate at the entrance to the Chavdar Tale park

Given the centrality of leisure in present-day uses of the Chavdar Tale park, it may be useful here to turn to Lefebvre's reflections on leisure. Just as Teltumbde warns of the dangers of appropriating Ambedkar, Lefebvre highlights the dangers of leisure as a means of co-option. He understands 'the case against leisure' well; that 'leisure is as alienated and alienating as labour; as much an agent of co-optation as it is itself co-opted; and both an assimilative and an assimilated part of the 'system' (Lefebvre, 1991, p. 383). That is, the 'system' allows us leisure so that we can return to work and serve the system better, refreshed. But Lefebvre does not stop on this pessimistic note. For him, the space of leisure ' is the very epitome of contradictory space' (p. 385). 
No matter how planned it is, it allows the body - disciplined by the division of labour and the monotony of the work routine - to reassert itself. Hence, concludes Lefebvre (Ibid p.385):

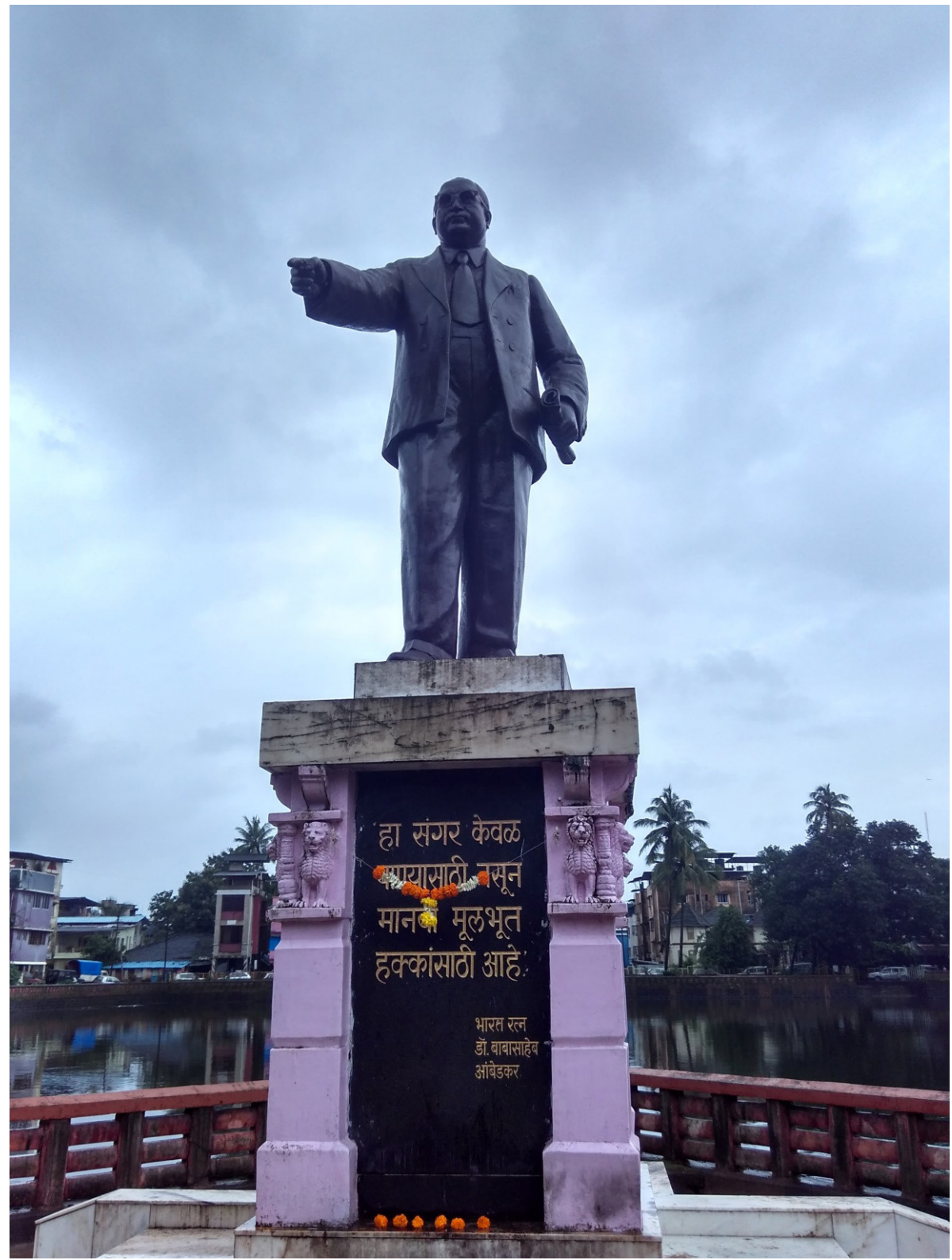

Figure 2:Ambedkar looms over visitors to Chavdar Tale

The space of leisure tends - but it is no more than a tendency, a tension, a transgression of 'users' in search of a way forward - to surmount divisions: the division between social and mental, the division between sensory and intellectual, and also the division between the everyday and the out-of-the-ordinary (festival). 
This provocative conclusion can be connected in several ways to the park abutting Chavdar Tale. Especially if one includes the adjoining function hall as part of the leisure area, the space certainly bridges the divides Lefebvre mentions - as kids run around the park, and lovers sit close together on the benches, activists meet inside the hall to plan upcoming protests and discuss the day's news. Political chatter spills out of the hall too, animating the conversations of the older men lounging and smoking bidis.

The space, with its strong Ambedkarite presence, bridges other divides as well, most notably caste divides. Though explicit residential segregation has lessened to some extent in Mahad, it still - like most Indian towns - bears strong traces of its casteist residential history, with upper castes more likely to live near the center of town, and hence to Chavdar Tale. The park, with its Buddhist gateway and Ambedkar statue, is clearly marked as a space that is friendly to Dalits, and many of the park regulars are fixtures from Ambedkarite political parties and social groups. But it is not an exclusively Dalit park - townspeople from across castes make use of its green space, helping to bridge longstanding social and spatial divisions.

Perhaps Lefebvre's most suggestive argument, though, is that the space of leisure can help undermine 'the division between the everyday and the... festival.' He seems to be referring to the festive nature of leisure spaces, and the way that they can - at least for a time - overturn the hierarchies and rigidities that rule our life. In the case of Chavdar Tale, though, the connection between the mundane and the spectacular is much more literal and direct: the everyday space of the park is transformed every March 20 and December 25 into a massive festival, and its connection to the attempted anti-caste revolution is renewed and reinvigorated.

\section{The Ambedkarite Festival,Through and Beyond Lefebvre}

The festival-as-revolution is a key figure in Lefebvre's thoughts, a concept that evolved with his writings on culture, politics and space from 1924 to 1968, skillfully summarized by Grindon (2013), who synthesizes many of Lefebvre's writings that are not yet available in English. Lefebvre was inspired by urban uprisings like the Paris Commune and the student- and worker-led protests, occupations and strikes that engulfed Paris and other parts of France in 1968, as well as by folk festivals like the ones he observed during his childhood in rural France. In addition to their claims of centrality, and their (temporary) overturning social hierarchies, festivals were also inspiring sites of cultural production.

Lefebvre fastidiously documented the folk festivals and cultural celebrations that took place during the Paris Commune, and included this as an appendix of his book-length study of the Commune. He also distanced himself from those, on the Left and Right alike, who saw the communards as essentially lumpen. Grindon (2013) describes this as 'Lefebvre's valourizing recognition of social movements as having discrete cultures and values, rather than being the unruly absence of culture'(p. 215). Thus Lefebvre suggests that the literal claim to (spatial) centrality in 'festivals' like the Paris Commune are accompanied by cultural claims to visibility and participation. 
These observations about subaltern festivities find resonance in the scholarship of Sharmila Rege, perhaps the most attentive English-language chronicler of Ambedkarite festivals. In her popular and academic writings, she has worked to overturn the complacent middle-class judgment that infused much English-language writing on Ambedkarite festivities. Like Lefebvre, she argues that the revelers she has chronicled did not represent 'the unruly absence of culture,' but a defiant and welldeveloped counter-culture.

As Rege (2008) notes, 'The usual middle class 'common sense' of the annual Ambedkarite gatherings is that these events are irrational/emotional and cause civic problems related to traffic and hygiene' (p. 16). Against this, Rege shows that the festivals have 'become a mode in which critical memory and history of the Dalit movement is reiterated, reinterpreted, and reindexed'(p. 16). Like the Paris Commune, these festivals re-imagine both the practicalities of everyday life and their symbolic expression.

Against the common middle-class charge that these festivals have just become crassly commercial, Rege suggests that the varied commerce at these events - from the selling of Buddhist literature to the hawking of food and to advertising of Ambedkarite music cassettes alongside raucous performances - are indicative of 'cooperative building efforts among Dalit communities'(p. 17). She is particularly sensitive to the ways in which Ambedkarite counter-publics spread through innovative, playful, and widely-distributed cultural forms.

In a way, this reads like an extension or confirmation of Lefebvre's (1991) assertion that we must embrace the 'vast store of non-formal knowledge embedded in poetry, music, dance and theatre'(p. 407). However, Rege's documentation and explanation of Ambedkarite cultural practices also pushes Lefebvre's theories, and suggests some of its limits.

To elaborate this point, it is necessary to delve into Lefebvre's theorization of space. Despite Lefebvre's (1991) sensitivity to the complex layering of space - the way, for instance, that 'nothing disappears completely' from social space, but 'continues to underpin what follows'(p. 229) - his overall argument in The Production of Space at times slips into Hegelian teleology, with history moving through the production of different spaces with an implausible dialectical neatness.

He speaks of 'the great dialectical movements that traverse the world-as-totality and help define it' (p. 218), and these three moments are linked to broad historical developments: first, a broadly agricultural 'moment,' in which production is 'still respectful of nature' and 'distills the sacredness of elements of it into religious... edifices'; second, an industrial moment, centred on accumulation, marked by abstractions, signs, and the sundering of space from time; and third, projected into the future, a moment of space and time, and of production and nature, reunited (p. 218).

This maps onto another dialectical movement that Lefebvre traces: from absolute space to abstract space, and finally (through transcending the contradictions of abstract space) to differential space. Lefebvre describes absolute space in terms of the religious or the sacred, the way that 'a part of [agro-pastoral] space is assigned a new role, and henceforth appears as transcendent, as sacred (i.e. inhabited by divine 
forces), as magical and cosmic'(p. 234). Such spaces often become the organic centre of emerging societies. But, Lefebvre suggests that in the broad historical sweep of time such spaces are all but swallowed up by the rationalizing logic of abstract space, the space of quantity, efficiency, capital. However, like capitalism as a whole, abstract space is riven with contradictions; we have already seen Lefebvre referring to spaces of leisure under capitalism as profoundly contradictory. These contradictions can give us glimpses of what Lefebvre calls 'differential space,' which will accentuate the positive differences that abstract space seeks to paper over, while at the same time restoring 'unity to what abstract space breaks up'(p. 52).

The suggestion, then, is that absolute space is superseded by abstract space, which in turn is superseded by differential space. Though, by Lefebvre's own admission, traces or layers of previous spaces remain, Lefebvre's neat account leaves little room for the re-emergence or re-valorization, for instance, of absolute (sacred) space, or potential merging of absolute and differential space. Looking at the Ambedkarite calendar of festivals, though, disrupts the neat linearity of Lefebvre's schema. It produces a vision of space that actually accords better with Lefebvre's more nuanced reflections on the intermingling and overlapping (the pastry-like nature) of complex social spaces.

First, given the prominence of neo-Buddhism in these festivities, it is difficult to argue that 'absolute space' withers away, and becomes a mere substratum on which other, more dynamic types of space are then built. The journey from one festivity to the other - from Bhima Koregaon to Mahad to Nagpur to Mumbai and back - is a neo-Buddhist pilgrimage, which can be read in Lefebvrian terms as the inscription of a new kind of absolute space on a hitherto Hindu-dominated landscape. This regional inscription also has concentrated nodes in places like the function hall outside Chavdar Tale, where, in the week leading up to the March 20 celebrations, the Bhartiya Baud Mahasabha leads a 10-day intensive session for the propagation of Navayana Buddhism. Here, we see something like a merging of absolute space and differential space.

Similarly, the monuments built around Mahad, to commemorate the Chavdar Tale action and the burning of the Manusmriti, do not fit easily into any one of Lefebvre's spatial categories. Lefebvre discusses monuments in the context of older societies, which have not yet been dominated by abstract space. For Lefebvre (1991), these monuments are not just tools of power, but also spatial modes of generating consensus by offering 'each member of a society an image of that membership' (p. 220). Appealing both to the senses and to the intellect, monuments project power and wisdom in such a way that 'the element of repression in it and the element of exaltation could scarcely be disentangled' (p. 220).

The monuments of Mahad are clearly of a different type. Lefebvre, in his discussion, presumes some sort of unity of the society in question, whereas the public life of Mahad is marked by fractures, particularly along caste lines. Further, while these monuments may be a display of power, they are clearly of power from below - of contesting a long history of monuments that consolidate caste Hindu rule. In a sense, then, these monuments too bridge absolute and differential space. And though these 
Mahad monuments are present throughout the year, they do not seem to have the more implacable solidity of traditional monuments. They are truly activated only twice a year (Figure 3), and thus have an unusual circular temporality that Lefebvre associates more with the body than with monuments.

Finally, the cultural production highlighted by scholars like Rege bears some resemblance to folk cultures lauded by Lefebvre, but suggests different spatialities, and perhaps more significantly, different temporalities. Lefebvre's specific invocations of folk culture are generally from the French countryside, from particular creative modes that Lefebvre sees as slowly being wiped out by the abstract space and its commodified culture. The cassettes highlighted by Rege, on the other hand, are transformations and reinventions of older cultural forms, and are also unabashedly commodities. As Rege (2008) notes, 'old forms of publicity like the community bhajan came to be thematically reformulated,' (p. 17) initially in the form of Ambedkari jalsa, and then in the widely-distributed cassette. These involved both the reworking of old artistic forms and the embrace of new styles (including, increasingly, electronic music) and new content (notably neo-Buddhist themes). These genres continue to be transformed, as the recent proliferation of Ambedkarite YouTube videos suggests.

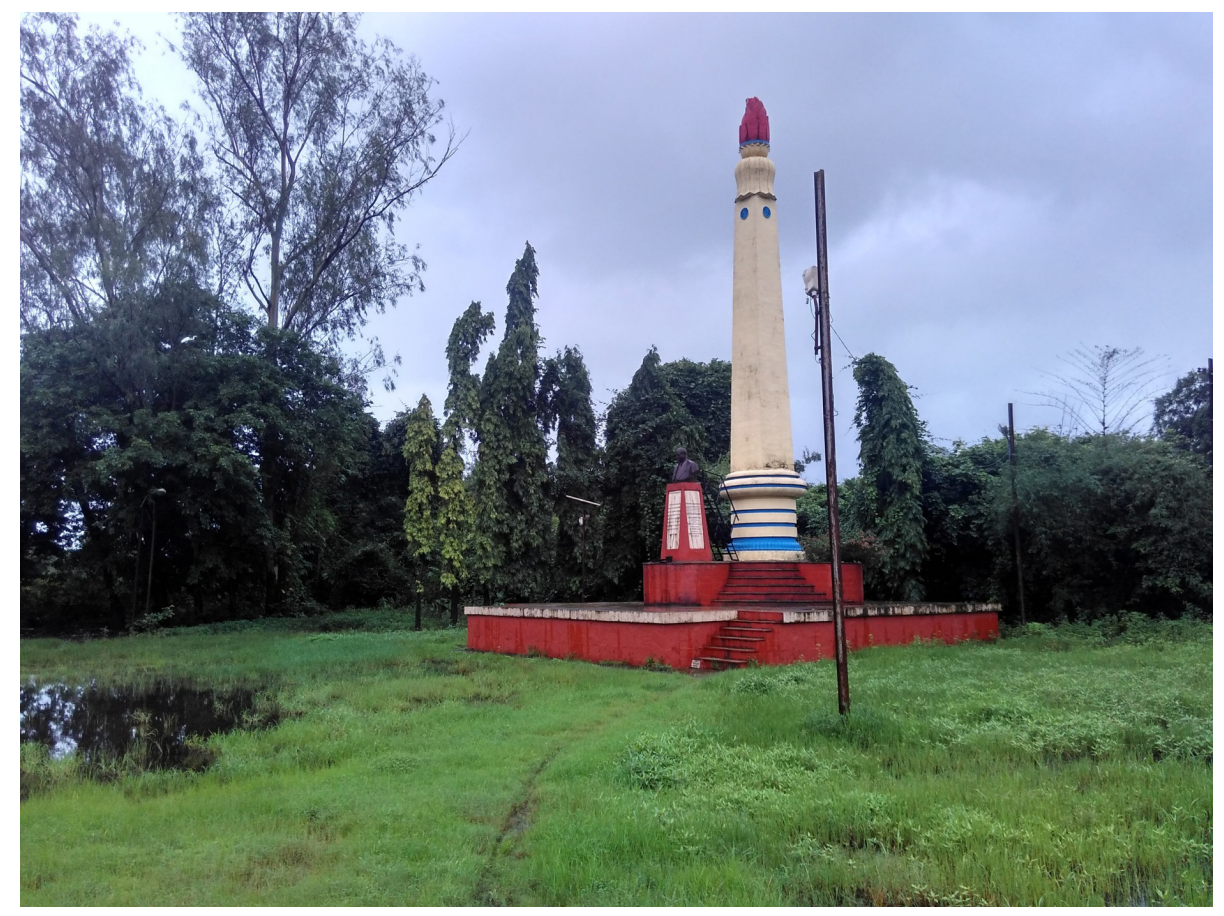

Fig. 3: The monument commemorating the burning of the Manusmriti, abandoned for most of the year (especially during the monsoon, when the grounds often flood)

\section{Return of the Revolution?}

Despite this cultural efflorescence, and the festiveness celebrated by Lefebvre and Rege in different ways, it is clear that a festival in itself does not necessarily usher in 
a new era of revolutionary change. In fact, though the middle classes may complain about the inconvenient crowds at Ambedkarite events, they have long been part of the accepted routine of the Maharashtrian year. The elites might grumble about them, but they hardly think them subversive or transgressive. If the festival inevitably dissolves back into everyday life, and everyday hierarchies, does it prefigure a future it can never actually realize?

Lefebvre, in his own time, realized the challenges of seeing the festival as a revolution. He muses: 'Up until now, the principle of Festival has stood for a divorce from life... Is this life's fate?'(Grindon 2013, p. 209). He thus recognizes the need for 'demonstrating how we may resolve the age-old conflict between the everyday and tragedy and between triviality and Festival' (Ibid, p. 212). He was aware that this was no simple task. A 'bureaucratic society of controlled consumption,' as Lefebvre (1984, p. 60) calls it, excels at appropriating, domesticating, and repurposing movements and cultural forms that originally seem transgressive.

How, then, to 'formulat[e] a revolutionary plan to... resurrect the Festival and gather together culture's scattered fragments for a transfiguration of everyday life?' (Ibid, p. 38). Questioning the idea that an eternal festival will simply emerge of its own accord, Lefebvre asks, 'Would it betray the revolution to... remember the questions left unresolved by the great revolutionaries: "What is the period of transition and change? What does it consist of?"” (Grindon 2013, p. 219).

Lefebvre clearly thinks that formulating a master plan for revolution would be counterproductive, as it would smother the very differences that a revolution-asfestival should liberate. Emphasizing the importance of spatial specificity, Lefebvre (1991) suggests the need for 'a challenge to central power from the "local powers", in the capacity for action of municipal or regional forces linked directly to the territory in question'(p. 382). Invoking the Gramscian language of hegemony, Lefebvre notes that such strategies must take careful account of 'the relative strength of sociopolitical forces' in specific cases (p. 382). Refusing to recommend particular 'plans'or 'programmes,' Lefebvre insists on following "the road of the "concrete," [which] leads via active theoretical and practical negation, via counter-projects or counterplans. And hence via an active and massive intervention on the part of the "interested parties"' (p. 419).

What does all this mean for Mahad? First, it means that the festivals at Mahad, or on the Ambedkarite circuit more generally, cannot be analyzed in isolation. They must be seen as particular moments in larger, complexly-configured and rapidly-shifting sets of social and political relations. As argued above, the initial Mahad satyagraha became possible due to increased flows of people, ideas, money, and activism across the Konkan and Bombay in an age of rapid political and economic change.

Arguably, the wave of radicalism - especially in terms of the anti-caste movement - peaked in the 1930s, for a multitude of political, economic, and social reasons (cf. Omvedt, 1994, p. 192). There have been other waves of Dalit assertion since then; the Dalit Panthers in the 1970s are a striking example. However, the Dalit Panthers (like the Republican Party of India before it) splintered into countless factions. Today, there are signs that a new nation-wide wave may be gathering force, from the massive protests 
and demands for land redistribution following anti-Dalit violence in Una, Gujarat (Teltumbde, 2017), to the rise of the Bhim Army in Uttar Pradesh (Sethi, 2016), to the widespread protests triggered by the death of Rohith Vemula in Hyderabad (EPW, 2016), to the emergence of new forms of struggle regarding Ambedkarite festivals in Maharashtra.

The latter happened most violently in the case of Bhima Koregaon, a celebration commemorating the defeat of the notoriously casteist Peshwas at the hands of the British, with Dalit support. For many years, this festival was seen as a routine part of the cultural landscape, gathering support from all political parties in the area. On January 1, 2018, however, the festival turned violent, with Hindutva gangs targeting Dalit participants. This led to a state-wide strike called by Prakash Ambedkar, who the political establishment had tried to sideline decades ago. This strike was successful, especially in Mumbai, highlighting the continued radical connections between town and countryside in Maharashtra. It also led to an intense state-led backlash against Dalit leaders and activists.

The event also had national ramifications that continue to reverberate. The day before the Bhima Koregaon celebrations, a group of progressive, Left and Dalit activists organized an event called the Elgar Parishad, which described the Bharatiya Janata Party (BJP) and the broader Hindu nationalist movement as the 'new Peshwas.' The event featured speeches by those representing the new national-level Dalit upsurge, including Rohith Vemula's mother, the national president of the Bhim Army, and a major leader from the Gujarat protests, Jignesh Mevani.

The event clearly rankled the state. Instead of investigating the role of Hindutva leaders in fomenting the Bhima Koregaon violence, the state has instead used Elgar Parishad as a pretext to arrest many activists under draconian anti-terrorist laws. The ferocity with which the state has cracked down on participants in these events suggests their unease with a possible national-level realignment of caste politics (cf. Crowley, 2018).

Although Mahad has not become the political flashpoint that Bhima Koregaon has, there are still indications that it is becoming more politically charged. Activists are beginning to look at the Mahad Satyagraha and its commemoration through a more pointedly political and confrontational lens. On March 20, 2018, a group of activists and civil societies figures commemorated the Mahad Satyagraha with a march which they called 'Shivrai to Bhimrai,' which traversed the route from Shivaji Maharaj's seventeenth-century Raigad Fort to Chavdar Tale in Mahad.

In part this was a symbolic attempt to quell the tensions between Marathas (who largely claim Shivaji as their community figurehead) and Dalits (who have a similar relationship with Ambedkar). These two groups are often in conflict at the village level, in both economic and social terms. The Bhima Koregaon clashes largely played out along the Maratha-Dalit axis, with Marathas rallying to the Hindutva side.

The organizers of the Shivrai to Bhimrai march were wagering that another alignment is possible. Drawing on an anti-Brahminical tradition that goes back to the theories and activism of Jotirao Phule, these activists claim that the most important social cleavage is between the upper castes and classes vs. all the rest (including both 
Marathas and Dalits). While local-level clashes often take the form of Maratha vs. Dalit, this hides the dominance of Brahmins and other upper-caste groups in urban areas and also in the ownership of businesses and property.

The march also sought to unify the various RPI factions and Dalit groups whose celebration of the Mahad satyagraha has become increasingly fractured. In recent years, major Ambedkarite leaders have erected separate stages for their Mahad commemorations, creating a clear spatial analog of the ideological and political divisions between them. But the youth from various factions joined the Shivrai to Bhimrai march, and insisted it end with a programme on one stage.

Will such attempts at suturing a new unity, both amongst Dalits and amongst nonBrahmins more broadly, be successful? It is, of course, too early to say. Activists face serious challenges in dealing with the very real Maratha-Dalit conflicts on the ground, while also reorienting the 'common sense' of Maharashtrians toward a different kind of caste/class analysis. Further, the role of religion in this new strategy is ambiguous. Its proponents clearly reject a polarizing Hindutva, but at the same time, in an effort to draw Maratha support, they downplay the equation of Mahad with Buddhism, arguably undercutting a powerful facet of new egalitarian productions of space. But perhaps the Shivrai-Bhimrai march can be seen as a new kind of pilgrimage, inscribing a space of non-Brahmin power and symbolism that can exist alongside neo-Buddhist circuits.

In this new phase of Dalit assertion, we can hope that, after a lull in which Ambedkarite festivals appeared to be routinized and defanged, they may re-emerge with a new political charge, echoing the pattern described by Lefebvre (1991): 'sudden uprisings followed by a hiatus, by a slow building of pressure, and finally by a renewed revolutionary outburst at a higher level of consciousness and action - an outburst accompanied, too, by great inventiveness and creativity'(p. 419).

As Lefebvre himself notes, such a pattern is far from certain. Further, given the way that Ambedkarite counterpublics trouble some of Lefebvre's neater dialectical progressions, we should be cautious of too easy an invocation of revolutionary transcendence. But inventiveness and creativity have surely been hallmarks of the Ambedkarite movement, and they stand as reminders that the revolution may yet be festive.

\section{References}

Ambedkar, B.R. (1979a). Annihilation of caste. In V. Moon (Ed.) Dr. Babasaheb Ambedkar: writings and speeches, Vol. 1 (pp. 23-96). Mumbai: Government of Maharashtra.

Ambedkar, B.R. (1979b). Castes in India: their mechanism, genesis and development. In V. Moon (Ed.)Dr. Babasaheb Ambedkar: writings and speeches, Vol. 1 (pp. 3-22). Mumbai: Government of Maharashtra.

Ambedkar, B.R. (1989). Revolt of the untouchables. In V. Moon (Ed.) Dr. Babasaheb Ambedkar: writings and speeches, Vol. 1 (pp. 247-258). Mumbai: Government of Maharashtra.

Chairez-Garza, J.F. (2014). Touching space: Ambedkar on the spatial features of untouchability. Contemporary South Asia, 22(1), 37-50.

Choudhury, S. (2018). Ambedkar and other immortals: an untouchable research programme. New Delhi: Navayana. 
Crowley, T. (2018). 200 years of anti-caste struggle. Jacobin Magazine. Retrieved from jacobinmag.com.

EPW (2016). Rohith's Living Legacy. Economic and Political Weekly 51(6), 7-8.

Feldhaus, A. (2003). Connected places: region, pilgrimage and geographical imagination in India. New York, NY: Palgrave Macmillan.

Gorringe, H. (2018). Ambedkar icons: whys and wherefores. In S. Yengde \& A. Teltumbde (Eds.)The radical in Ambedkar: critical reflections (pp. 328-339). Gurgaon: Penguin Random House India.

Gramsci, A. (1971). Selections from the prison notebooks of Antonio Gramsci (Q. Hoare and G. N. Smith, Trans.). London: Lawrence and Wishart.

Grindon, G. (2013). Revolutionary romanticism. Third Text, 27(2), 208-220.

Guru, G. (2012). Experience, space and justice. In G. Guru \& S. Sarukkai (EDS.), The cracked mirror: an Indian debate on experience and theory. Delhi: Oxford University Press.

Hart, G. (2016). Relational comparison revisited: Marxist postcolonial geographies in practice. Progress in Human Geography, 1-24. doi:10.1177/0309132516681388.

Jain, K. (2014). The handbag that exploded: Mayawati's monuments and the aesthetics of democracy in post-reform India. In P. Chatterjee, T. Guha-Thakurta\& B. Kar (Eds.)New cultural histories of India: Materiality and practices (pp. 139-179). New Delhi: Oxford University Press.

Jaoul, N. (2006). Learning the use of symbolic means. Contributions to Indian Sociology, 40(2), 175-207. doi:10.1177/006996670604000202.

Lee, J. (2017). Odor and Order: How caste is inscribed in space and sensoria. Comparative Studies of South Asia, Africa and the Middle East, 37(3), 470-490. DOI: 10.1215/1089201x4279188

Lefebvre, H. (1984). Everyday life in the modern world (S. Rabinovitch, Trans.). New Brunswick, NJ: Transaction Books.

Lefebvre, H. (1991). The production of space. (D. Nicholson-Smith, Trans.). Oxford: Basil Blackwell.

Lefebvre, H. (2003a). The style of the Commune. In S. Elden, E. Lebas\& E. Kofman (Eds.) Henri Lefebvre: Key Writings (pp. 188-189). New York, NY: Continuum.

Lefebvre, H. (2003b). The urban revolution. Minneapolis: University of Minnesota Press.

Lefebvre, H. (2014). Critique of everyday life: the one-volume edition. London: Verso.

Marx, K. (1933). The Civil War in France. New York, NY: International Publishers.

Mitchell, D. and Villanueva, J. (2010). Right to the city. In R. Hutchison (Ed.)Encyclopedia of urban studies (pp. 668-672). Thousand Oaks, CA: Sage Publications.

Omvedt, G. (1994). Dalits and the democratic revolution: Dr. Ambedkar and the Dalit movement in colonial India. New Delhi: Sage Publications.

Omvedt, G. (2011). Building the Ambedkar revolution: SambhajiTukaram Gaikwad and the kokan Dalits. Mumbai: BhashyaPrakashan.

Omvedt, G. (2013). Ambedkar: towards an enlightened India. Penguin e-book. (Original work published 2004)

Mitchell, D. and Villanueva, J. (2010). Right to the City. In R. Hutchison (Ed.), Encyclopedia of Urban Studies (pp. 668-672). Thousand Oaks, CA: Sage Publications.

Rao, A. (2009). The caste question: Dalits and the politics of modern India. Berkeley, CA: University of California Press.

Ross, K. (2015). Communal luxury: the political imaginary of the Paris Commune. London: Verso. 
Rege, S. (2008). Interrogating the thesis of 'irrational deification.' Economic \& Political Weekly, 43(7), 16-20.

Sethi, Aman. (2016). Ambedkar's army: A Dalit force fights atrocities in Uttar Pradesh. The Quint. retrieved from thequint.com

Tartakov, G. M. (1990). Art and identity: the rise of a new Buddhist imagery. Art Journal (New York. 1960), 49(4), 409-416.

Teltumbde, A. (2016). Mahad: the making of the first Dalit revolt. Delhi: Aakar Books.

Teltumbde, A. (2017). Azadi kooch: towards a new grammar of the Dalit struggle. Economic and Political Weekly 52(31), 10-11.

Teltumbde, A. (2018). Republic of caste: thinking equality in the time of neoliberal Hindutva. New Delhi: Navayana Publishing.

Zelliot, E. (2004). Ambedkar's World: the Making of Babasaheb and the Dalit movement. New Delhi: Navayana Publishing.

Zelliot, E. (2011). Connected people: pilgrimage in the structure of the Ambedkar movement. Voice of Dalit, 4(1), 1-6. 